\title{
LA REPRESENTACIÓN POLÍTICA EN LA DIALÉCTICA REPRESENTANTES/REPRESENTADOS: NECESARIA “REANIMACIÓN” DE LA TEORÍA DE LAS ÉLITES
}

\author{
Mª NIEVES ALONSO GARCÍA*
}

Recibido: 22/08/2018

Aceptado: 05/10/2018

SUMARIO: I. CUESTIONES PRELIMINARES: EL SIGNIFICADO DE LA REPRESENTACIÓN POLÍTICA. 1. RELACIÓN ENTRE REPRESENTANTES Y REPRESENTADOS. 2. ¿QUIÉN NOS REPRESENTA?: UNA REFLEXIÓN DESDE LA TEORÍA DE LAS ÉLITES. II. LA CONTRADICCIÓN DE LA REPRESENTACIÓN POLÍTICA: UNA PERSPECTIVA HISTÓRICA. III. A MODO DE CONCLUSIÓN. IV. REFERENCIAS BIBLIOGRÁFICAS.

SUMMARY: I. PRELIMINARY ISSUES: THE MEANING OF POLITICAL REPRESENTATION. 1. RELATIONSHIP BETWEEN REPRESENTATIVES AND REPRESENTED. 2. WHO REPRESENTS US ?: A REFLECTION FROM THE THEORY OF THE ELITES. II. THE CONTRADICTION OF POLITICAL REPRESENTATION: A HISTORICAL PERSPECTIVE. III. IN CONCLUSION. IV. BIBLIOGRAPHIC REFERENCES.

Resumen: La ampliación de la distancia entre representantes y representados ha supuesto el caldo de cultivo en el que surgen con fuerza las demandas de una regeneración democrática y el replanteamiento del sistema de representación política. En esta coyuntura cobra más sentido que nunca esta reflexión en torno a la teoría de la representación. Una vez analizados desde una perspectiva descriptiva y someramente sus dimensiones, es preciso realizar una disquisición sobre los sujetos responsables de la misma. Con este objetivo, resulta conveniente ejecutar un breve análisis de los teóricos clásicos de las élites para concluir en una consideración de las élites en la actualidad.

Abstract: The widening of the distance between representatives and represented has been the breeding ground in which the demands of a democratic regeneration and the rethinking of the system of political representation arise. At this juncture, this reflection about the theory of representation acquires more meaning than ever. Once analyzed from a descriptive perspective and briefly its dimensions, it is necessary to make a disquisition on the subjects responsible for it. With this objective, it is convenient to execute a brief analysis of the classical theorists of the elites to conclude in a consideration of the elites at present.

Palabras clave: representación, desafección, regeneración, élites

Key words: representation, disaffection, regeneration, elites

\footnotetext{
* Profesora Doctora de Derecho Constitucional. Coordinadora del Grado en Derecho. Universidad Isabel I. https://www.ui1.es/.marianieves.alonso@ui1.es. https://orcid.org/0000-0002-1091-6819
} 


\section{CUESTIONES PRELIMINARES: EL SIGNIFICADO DE LA REPRESENTACIÓN POLÍTICA}

En una coyuntura en la que surgen con fuerza demandas de regeneración democrática y replanteamientos del sistema de representación política ${ }^{1}$ cobra más sentido que nunca esta reflexión en torno a su basamento teórico.

La democracia representativa ha experimentado una serie de transformaciones ${ }^{2}$ a lo largo de su desarrollo histórico. Nos hallamos ante un concepto polisémico, que ha ido variando a lo largo del tiempo. Las democracias actuales son el sedimento de distintas tradiciones históricas, de las que se han ido incorporando elementos que han acabado por ser componentes imprescindibles de aquellas ${ }^{3}$. Y, dentro de esta visión amplia, resulta evidente el hecho de que hablar hoy de democracia es hablar de democracia representativa. La representación se alza como el núcleo de la democracia contemporánea ${ }^{4}$.

El concepto de representación surge del progresivo cambio y evolución que se produce ya desde finales de la Edad Media ${ }^{5}$ pero, fundamentalmente en la Edad Moderna, a partir de una concepción consistente en que la soberanía recae en el Monarca a otra posición basada en que la soberanía recae en la Nación, la cual, entendida como el conjunto de ciudadanos de derechos políticos, nombra a unos representantes que en su nombre ejercen el gobierno de la comunidad.

Esta concepción se materializa en el comienzo de la Edad Contemporánea y las revoluciones Liberales del siglo XVIII ${ }^{6}$. La representación estamental de la Edad Media dio paso a la representación nacional y el mandato imperativo propio de aquella cedió su lugar al mandato representativo del Estado liberal.

El Estado moderno no se presenta como una estructura estática y aislada, sino como el resultado, eventual y muy variado, de un proceso de evolución, competición y adaptación, causado tanto por shocks exógenos (económicos, políticos o bélicos), como por movilizaciones políticas y conflictos endógenos. Este proceso multicausal, muy diferente en sus ritmos, características y cristalizaciones según los países, condensa, en grado diverso, el efecto de varios factores. Estos últimos, en cuanto variables explicativas, diferenciadas y a la vez interdependientes, se combinan y explican, en mayor o menor

\footnotetext{
1 Vid. TORRES DEL MORAL, A., “Democracia y representación en los orígenes del Estado constitucional, Revista de estudios políticos, n. 203/1975, pp. 145-212.

${ }^{2}$ Respecto a las transformaciones del Estado es especialmente significativa la obra de GARCÍA PELAYO, M., Las transformaciones del Estado contemporáneo, Alianza Editorial, Madrid, 1977.

3 CEBRIÁN ZAZURCA, E., Sobre la democracia representativa. Un análisis de sus capacidades e insuficiencias, Universidad de Zaragoza, Zaragoza, 2013, p.15.

${ }^{4} \mathrm{La}$ idea de representación es el presupuesto cardinal sobre el cual se apoya la condición misma del Parlamento como institución representativa. GARRORENA MORALES, A., Representación política y Constitución democrática, Cuadernos Civitas, Madrid, 1991, p. 18.

${ }^{5}$ En la Edad Media existía un principio de origen romano, que se formulaba del siguiente modo: "quod omnes tangit, ab omnibus tractari et approbari debet" (lo que, a todos afecta, debe ser tratado y aprobado por todos). En este contexto histórico significaba que un deseo de arriba había de lograr la aprobación de abajo (op. cit. pág. 36).

${ }^{6}$ Sobre este período histórico, Vid. TOUCHARD, J., Historia de las ideas políticas, Tecnos, Madrid, 1990, pp. 301-340.
} 
medida, en cada Estado concreto, dependiendo de los distintos contextos y ecologías en las que este se desarrolla ${ }^{7}$.

Durante los siglos señalados se produce un fortalecimiento de las monarquías europeas que las lleva a volverse absolutas, pero, en paralelo a eso, se produce también un desarrollo de un nuevo paradigma basado en la individualidad.

En dicha evolución se han producido tres transformaciones clave: la democracia liberal del siglo XIX ${ }^{8}$, pasando por la democracia de partidos del siglo XX y hasta la denominada "democracia de audiencia" ${ }^{9}$ de principios del siglo XXI. Todas ellas han afectado a los elementos fundamentales de la representación política, a la manera de entender cómo debe ser dicha representación. En ese proceso, sin embargo, ciertos principios se han mantenido, aunque su puesta en práctica se ha ido modificando: la elección de representantes a intervalos regulares; la independencia relativa de los representantes; la libertad de la opinión pública; y la toma de decisiones mediante el debate y la deliberación ${ }^{10}$.

El mantenimiento de estos principios fundamentales de la democracia representativa quiebra en la práctica actual, siendo necesario en los albores del siglo XXI, la recuperación de la esencia de la representación, así como la acomodación a los nuevos retos y demandas de los ciudadanos.

\section{Relación entre representantes y representados}

La relación entre representantes y representados ha sido estudiada, entre otros, por Schmitt quien distingue entre representación mediante elecciones, que es siempre a su juicio una representación inauténtica, es decir, una representación de intereses -dominio

\footnotetext{
${ }^{7}$ MAÍZ SUÁREZ, R., “El Dios mortal ¿implica la globalización una progresiva desaparición del Estado?”, Araucaria: Revista Iberoamericana de filosofía, política y humanidades, n. 37/2017, p.4.

${ }^{8}$ Sobre este particular, Vid. VÍRGALA FORURIA, E., "Representación, parlamentarismo y democracia participativa en España”, GARCÍA HERRERA, M.A. / ASENSI SABATER, J. / BALAGUER CALLEJÓN, F. (Coords.), Constitucionalismo crítico, Liber amicorum Carlos de Cabo Martín, Tomo II, Tirant lo Blanch, Valencia, 2016, pp. 1124-1134.

${ }^{9}$ Bernard Manin considera que la representación democrática estaría experimentando una transición entre dos tipos ideales que designa como “democracia de partidos” y “democracia de audiencia”. Dicha transición estaría afectando, entre otras, a dos dimensiones del orden democrático: la elección y el grado de autonomía de los representantes: mientras que en la democracia de partidos los representantes se reclutan entre activistas y los funcionarios de partido, la democracia de audiencia prima la relevancia mediática de los candidatos, dando protagonismo a los expertos en medios y a los candidatos de mayor habilidad mediática. En la democracia de partidos, el representante es un simple delegado del partido, el cual ocupa un lugar central y mediador entre representantes y representados, en tanto que la democracia de audiencia pone en primer plano al representante, el cual se vale de la citada relación de confianza personal con los representados para ganar autonomía personal respecto al partido. La segunda de las dimensiones es el patrón de opinión pública: mientras en la primera “todas las expresiones de la opinión pública están estructuradas siguiendo divisiones partidistas, en la segunda los canales de comunicación son en su mayor parte políticamente no partidistas, lo que propicia una cierta uniformización de los mensajes vertidos por los medios, así como una cierta transversalidad de las preferencias ciudadanas (con relativa independencia de sus preferencias electorales). GONZÁLEZ RODRÍGUEZ, J.J., "Escenarios de futuro para la democracia española. Democracia de partidos y democracia de audiencia”, NAVAJAS ZUBELDÍA, C. / ITURRIAGA BARCO, D. (Coords.), España en democracia: Actas del IV Congreso de Historia de Nuestro Tiempo, 2014, pp. 123-131.

${ }^{10}$ MANIN, B., Los Principios del Gobierno Representativo, Alianza Editorial, Madrid, 1997, pp. 237-286.
} 
de los partidos ${ }^{11} \mathrm{y}$ de los intereses económicos- y representación espiritual, que se manifiesta no por las elecciones, sino por la identificación del pueblo con sus líderes mediante la aclamación o el asentimiento-. Esta representación es para Schmitt la única representación auténtica, pues no se verifica a través de procedimientos, ya que es algo existencial. Por ello el representante no es un delegado de la voluntad de los representados, ya que por principio esa voluntad no existe -lo que hay es una diversidad de voluntades antagónicas-, es imposible que pueda delegarse; por el contrario, mediante esa representación, el representante encarna lo que hay de homogéneo entre los representados, expresando así una voluntad popular que solo es capaz de manifestarse por obra del representante mismo, por su cualidad para identificarla ${ }^{12}$.

Otra respuesta a la relación entre representantes y representados es desarrollada por Max Weber, quien considera que los partidos políticos tienen como criterio básico la búsqueda del poder. Sostiene a este respecto y vinculado al contexto norteamericano pero extensible al resto, que "los partidos norteamericanos son organizaciones de cazadores de cargos, cuyos mutables programas son redactados para cada elección sin tener en cuenta otra cosa que la posibilidad de conquistar los votos”13.

Hanna F. Pitkin es uno de los máximos exponentes en lo que a teoría de democracia representativa se refiere, autora de una de las aportaciones más completas en la materia. Pitkin define la representación como la actuación de los representantes en interés de los representados de una manera sensible ante ellos ${ }^{14}$. El representado deber ser también capaz de acción y de juicio independientes, y no comportarse meramente como necesitado de cuidado ${ }^{15}$. Asimismo, considera a la representación como un fenómeno de carácter multidimensional que incluye al menos cuatro dimensiones:

En la primera de ellas, se concibe la representación como autorización y como responsabilidad $^{16}$. El representante es autorizado a actuar en nombre del representado. La representación en su dimensión formal ${ }^{17}$ está vinculada con el conjunto y la práctica de normas, reglas y procedimientos para la selección de los representantes por parte de los representados. Esta dimensión incluye, por un lado, la autorización, de acuerdo con la cual un representante es alguien que ha sido autorizado para actuar en nombre de otro. Se parte así de un trato, de un otorgamiento de autoridad, en el que los representados pueden establecer, ex ante, mandatos, deseos o peticiones para los representantes.

\footnotetext{
${ }^{11} \mathrm{El}$ dominio de los partidos dentro de la democracia representativa ha llevado a autores como Laporta a considerar al Estado democrático actual una "democracia representativa de partidos", (LAPORTA SAN MIGUEL, F.J., "El cansancio de la democracia”, Claves de la razón crítica, n.99/2000, pp. 20-25) o a Torres Moral como un mandato imperativo de partidos (TORRES DEL MORAL, A., "Réquiem por el mandato representativo", Revista de Derecho Político, n. 81/ 2011, pp. 11-60).

${ }^{12}$ SCHMITT, C., Sobre el parlamentarismo, Madrid, Tecnos, 1990.

${ }^{13}$ WEBER, M., Economía y sociedad, Fondo de cultura económica, México, 1992.

${ }^{14}$ García Roca define la representación como "una atribución de competencia y de legitimidad a ciertos cargos públicos para decidir acerca de la voluntad de los órganos del Estado con arreglo a un proyecto o programa presentado en una concurrencia electoral ante los ciudadanos" GARCÍA ROCA, J., Cargos públicos representativos. Un estudio del artículo 23.2 de la Constitución, Aranzadi, Navarra, 1999, p. 63. ${ }^{15}$ FENICHEL PITKIN, H., El concepto de representación, Centro de Estudios Políticos y Constitucionales, Madrid, 2014, p. 265.

${ }^{16}$ Un interesante estudio sobre la responsabilidad de los representantes puede verse en: BUSTOS GISBERT, R., Calidad democrática, Marcial Pons, Valencia, 2016.

${ }^{17}$ La representación como autorización tiene como punto de partida la obra de Thomas Hobbes y ha sido desarrollada por la doctrina alemana por autores como Loewenstein, Plamenatz o Voegelin.
} 
Asimismo, esta perspectiva formalista de la representación también implica la accountability, u obligación del representante de rendir cuentas ante sus representados ${ }^{18}$. La representación como responsabilidad considera que los representantes han de estar sujetos a mecanismos de rendición de cuentas que aseguren un cumplimiento cierto y efectivo de su cometido. Así las elecciones suelen ser consideradas un mecanismo fundamental en relación con la dimensión formal de la representación.

La segunda de las dimensiones vincula a la representación como correspondencia, descripción o reflejo ${ }^{19}$. Alude a las características, funcionales o sociodemográficas, identificativas comunes a los representados y representantes. Hace referencia a la relación entre determinadas características que se supone o se espera compartan representantes y representados. Se habla, en este sentido, de representatividad funcional o social, de representación como espejo. Se pueden diferenciar dos clases de representación descriptiva: la microscópica, en la que el conjunto de la asamblea constituye un microcosmos o muestra representativa del electorado, y la selectiva, en la que el diseño institucional otorga a grupos seleccionados mayor representación descriptiva de la que tendrían por el sistema electoral, para aproximar el peso cuantitativo de esos grupos en la asamblea a su presencia efectiva (cuantitativa) en la sociedad.

Esta clase de representación se centra en una idea cercana a la representatividad ${ }^{20}$ entendida como similitud entre los representantes y los representados, como reflejo de estos en aquellos.

Conforme a la representación descriptiva cuanto mayor sea la semejanza, más perfecta será la representación obtenida.

\footnotetext{
${ }^{18}$ Sobre este particular, Vid. ABELLÁN LÓPEZ, Ma A., "El sistema de control externo multinivel español: Rendición de cuentas, desafíos y oportunidades”, Revista Cuadernos Manuel Giménez Abad, n. 13/2017, pp. 51-65; DE LA FUENTE Y DE LA CALLE, $\mathrm{M}^{\mathrm{a}} \mathrm{J}$., "Reflexiones acerca de la transparencia como instrumento de mejora de la gestión pública, Revista española de control externo, n. 56/2017, pp. 43-75; PAJA FANO, M., “Un nuevo marco legal para la evaluación”, Gestión y análisis de políticas públicas, n. 17/2017, pp. 6-25; BELMONTE MARTÍN, I., "De la opacidad a la cultura de la transparencia y de la rendición de cuentas. Una aproximación a la visibilización de los lobbies para la regeneración democrática”, CALABUIG PUIG, Ma.A. / SANJUÁN ANDRÉS, F.J. (Coords.) / TUR AUSINA, R. (Dir.), Poderes públicos y privados ante la regeneración constitucional democrática, Dykinson, Madrid, 2016, pp. 251265. MARTÍNEZ, A. / CRESPO MARTÍNEZ, I., "Receptividad y accountability en España", MARTÍNEZ, A. (Coord.), Representación y calidad de la democracia en España, Tecnos, Madrid, 2006, pp. 101-116.

${ }^{19}$ Esta concepción de la representación, denominada proporcionalista, es defendida por autores como John Stuart Mill. Para Mill el tipo ideal de Gobierno perfecto es aquel en el cual la soberanía, o supremo poder de control, reside, en última instancia, en todo el agregado comunitario, de manera que cada individuo tiene voz en el ejercicio de la soberanía y, además, de tiempo en tiempo, es llamado a participar en el Gobierno desempeñando alguna función pública, sea local o general. La participación del pueblo en las funciones públicas satisface las exigencias de la convivencia y por mínima que sea es útil. Por consiguiente, esa participación debe ser tan amplia como lo permita el grado de cultura de la comunidad y no puede exigirse menos que la admisión de todos en una parte de la soberanía, pero como, salvo en pequeñas ciudades, no es posible que todos participen personalmente, sino solo en una porción muy pequeña, el tipo ideal de un Gobierno perfecto es el Gobierno representativo. La mayoría del pueblo carece de intervención e interés en todos los grandes asuntos de la política, o si algo sabe, su ciencia es una ciencia dilettanti, como el saber mecánico de las personas que nunca han manejado un útil. STUART MILL, J., Libertad. Gobierno representativo. Esclavitud femenina, Tecnos, Madrid, 1965, p. 178.

${ }^{20}$ Un interesante análisis sobre la representatividad puede encontrarse en: VALENCIA ESCAMILLA, L., "Representatividad, legitimidad y credibilidad parlamentaria”, Revista Mexicana de Ciencias Políticas y Sociales, n. 162/1995, pp. 73-78.
} 
A este respecto se puede evidenciar la diferencia entre representación y representatividad ${ }^{21}$. Representación y representatividad no son términos equivalentes. Si la primera -la representación- se refiere a la noción de autoridad-el representante del Estado, los órganos de representación-, la otra -representatividad- se funda en el momento de la libertad y encuentra su base en el consentimiento, en la correspondencia, en la adhesión a la sentencia popular. En otras palabras, en la "consonancia que se establece entre gobernantes y gobernados cuando los primeros consiguen traducir en fórmulas jurídicas los valores que se manifiestan tan preeminentes en la comunidad que los ha expresado"22.

Es oportuno citar la postura de Arce Janáriz ${ }^{23}$ relativa a la matización entre los conceptos de representación y representatividad a la luz de la procedencia del titular del escaño $^{24}$. Distingue este autor entre el valor, representatividad, y el instrumento del que esta se sirve, la representación. Mientras la representatividad afecta a la correspondencia entre representantes y representados, a su complicidad ${ }^{25}$, la representación apunta esencialmente hacia la responsabilidad que vincula el representante al representado.

En tercer lugar, considera la representación como identificación simbólica, que implica una relación emocional entre representante y representado. Desde esta dimensión se tiene en cuenta la capacidad del representante, o su partido, para evocar sentimientos y actitudes de identidad con los representados. Es la que se fija no tanto en sus caracteres o contenidos, sino en cómo la representación es percibida y evaluada por los representados, en función de la capacidad por parte del representante para representar, identificar o evocar sentimientos o actitudes. Se trata del aspecto de la representación que permite a los representados identificarse con el representante, sentir que comparten un proyecto o un mismo imaginario colectivo.

Este tipo de representación posee una cara negativa en tanto en cuanto para que exista una representación simbólica efectiva, han de producirse en quien es el destinatario de esa representación una serie de mecanismos difícilmente defendibles desde una perspectiva racional por la emotividad de los mismos.

En la cuarta de estas dimensiones, Pitkin considera la representación como una relación sustantiva. La representación significa aquí actuar en interés de los representados, de una manera sensible, receptiva, ante ellos. Atiende al contenido de la representación en términos de intereses, políticas y resultados materiales, respecto de los

\footnotetext{
21 "En relación con la representatividad y la democracia directa, los instrumentos participativos pueden contemplarse como mecanismos destinados a hacer presentes en otros ámbitos del Estado algunas de las demandas sociales que los partidos han sido incapaces de incorporar y que son mediadas por organizaciones distintas que reclamarían un espacio propio de integración e incluso, como mecanismos de incidencia en el propio funcionamiento interno de los partidos políticos”. CRIADO DE DIEGO, M., Participar. La ciudadanía activa en las relaciones estado sociedad, Dykinson, Madrid, 2014, p. 175.

${ }^{22}$ MARTINES, T.: Diritto costituzionale, Giuffre, Milán, 2013, p. 115.

${ }^{23}$ ARCE JANÁRIZ, A., “Tránsfugas y portavoces en el Grupo Mixto (Dictamen sobre la constitucionalidad de la portavocía del Grupo Parlamentario Mixto preparada por el grupo de trabajo para la reforma del Reglamento de la Junta General del Principado de Asturias)”, Revista de las Cortes Generales, n. 40/1997, pp. 161-162.

${ }^{24}$ Respecto a tránsfugas, Vid.: SEIJAS VILLADANGOS, M. ${ }^{a}$ E., "Representación democrática, partidos políticos y tránsfugas”, Teoría y Realidad Constitucional, n.6/2000, pp. 163-188.

${ }^{25}$ Bastida Freijedo, se decanta por considerar a esa complicidad como lealtad. BASTIDA FREIJEDO, F.J., "Derecho de participación a través de representantes y función constitucional de los partidos políticos", Revista Española de Derecho Constitucional, n. 21/1987, p. 123.
} 
que debería haber congruencia en opinión tanto de representantes como de representados. Implica que el representante debe promover el interés del representado, a quien se considera capaz de actuar y evaluar, pero de forma que no se oponga a lo que se hace en su nombre. El representante debe actuar en beneficio de su representado, pero la forma en la que lo hace debe ser sensible y receptiva a los deseos de este. El representante no necesita actuar literalmente en respuesta a los deseos del representado, pero los deseos de este deben ser potencialmente considerados y relevantes. La actuación del representante en interés de los representados ha de ser constatable por estos y de forma receptiva hacia ellos, esto es, implementando políticas deseadas por los votantes, en función de deseos y demandas detectadas por los representantes.

El concepto de representación se configura como una continua tensión entre el ideal y el logro. Esta tensión no debería arrastrar ni a abandonar el ideal, retrocediendo a una definición operativa que acepta todo lo que hacen aquellos que comúnmente son designados como representantes, ni a abandonar su institucionalización y escapar de la realidad política. Antes, al contrario, esa tensión debería hacer presente un desafío continuo, aunque no desesperanzado: construir instituciones y entrenar a individuos ${ }^{26} \mathrm{de}$ tal forma que se comprometan en la consecución del interés público, en la genuina representación del público; $\mathrm{y}$, al mismo tiempo, seguir siendo críticos con tales instituciones y con tales aprendizajes con el fin de que siempre se muestren abiertos a posteriores interpretaciones y reformas ${ }^{27}$.

Estas dimensiones se relacionan entre sí de tal forma que pueden reforzarse o contradecirse, pero todas están presentes, de alguna manera, en la concepción democrática de la representación.

Desde los años noventa, la crisis política ha ido acompañada de una crítica a la insuficiencia del concepto y/o del enfoque proporcionado por Pitkin ${ }^{28}$. Así, buena parte de los teóricos han centrado sus estudios en las dimensiones de representación "formalistas", referidas a la noción de autorización y de responsabilidad, que se vinculan directamente a los procesos electorales.

Como resultado de los procesos electorales, se concibe un modelo de representación basado en relación mandante-agente. Sin embargo, esta visión puede ser excesivamente restrictiva, ya que la teoría y el análisis empírico han demostrado que los representantes pueden actuar legítimamente de forma distinta. El incumplimiento de las promesas electorales o la realización de medidas controvertidas no se traducen automáticamente en una pérdida de confianza por parte de los electores, poniendo de manifiesto que la relación mandante-agente es compleja y depende en buena medida de la información que reciben los electores y la reputación política de los representantes.

Asimismo, las transformaciones en los entramados institucionales, tanto estatales como internacionales, han llevado a reflexiones teóricas acerca de la representación fuera del ámbito nacional o electoral. El crecimiento e intensificación de la representación

\footnotetext{
${ }^{26}$ Podría deducirse que Pitkin hace una referencia a la formación de una élite de representantes.

${ }^{27}$ FENICHEL PITKIN, H., El concepto de representación, Centro de Estudios Políticos y Constitucionales, Madrid, 2014, p. 302.

${ }^{28} \mathrm{Al}$ respecto de este particular, Vid. GARRORENA MORALES, A., Escritos sobre la democracia. La democracia y la crisis de la democracia representativa, Centro de Estudios Políticos y Constitucionales, Madrid, 2015.
}

Revista de Estudios Jurídicos no 18/2018 (Segunda Época)

ISSN-e 2340-5066. Universidad de Jaén (España)

Versión electrónica: rej.ujaen.es 
“informal” (grupos de interés, ONGs, etc) siendo inevitable, puede socavar la igualdad que promueve y posibilita la representación electoral.

A partir de estos presupuestos clásicos sobre la representación ${ }^{29}$, otros teóricos como Sartori han desarrollado teorías sobre la relación de representación. El citado autor considera que representar significa actuar en nombre de otro para defender sus intereses, e insiste en que la representación política implica: receptividad -responsiveness-, pues los representantes deben escuchar a su electorado y ceder a sus demandas, rendición de cuentas -accountability-, pues los representantes han de responder, aunque difusamente, de sus actos y la posibilidad de destitución de los representantes, si bien solo en determinados momentos ${ }^{30}$. Sartori aboga por considerar que la representación es algo distinto de la representatividad -su uso sociológico-, que incorpora la idea de similitud, identificación o características compartidas entre representantes y representados. Serían conceptos diferentes, aunque la compresión de la política representativa dependa de ambos.

Es especialmente significativa en esta línea la teoría de Anna Mansbrigde ${ }^{31}$, quien identifica cuatro formas de representación en las democracias modernas: la promisoria los representantes serán evaluados por las promesas que hacen en las campañas electorales- ${ }^{32}$; la anticipatoria -los representantes se centran en lo que piensan que sus electores recompensarán en las próximas elecciones y no en lo que prometieron durante la campaña de la elección anterior-; la giroscópica -los representantes realizan una labor introspectiva para derivar de su propia experiencia los intereses y principios que sirvan de base para su acción-; y la subrogada -tiene lugar cuando los representantes representan a electores que no pertenecen a su circunscripción-. De estas cuatro facetas, solo la primera es de carácter formal, es decir, es la que se manifiesta mediante los mecanismos de autorización y responsabilidad.

Existe la tendencia en la actualidad de cuestionar que la representación consista solo en la relación entre electos y electores mediante el voto, y únicamente en el momento electoral; la representación también se desarrolla durante el período de ejercicio del mandato y los sistemas electorales pueden producir diferentes efectos ${ }^{33}$. También se

29 “La invención o descubrimiento de la representación ha sido tan decisiva para el desarrollo político de Occidente y el mundo, como ha sido para el desarrollo técnico de la humanidad la invención de la electricidad, el motor de explosión o la fuerza atómica”. LOEWENSTEIN, K., Teoría de la Constitución, Ariel, Barcelona, 1986, p. 20.

30 SARTORI, G., "En defensa de la representación política”, Claves de la Razón Práctica, n. 91/1999, pp. 2-6.

${ }^{31}$ MANSBRIDGE, J., “Rethinking representation”, American Political Science Review, n. 4/2003, pp. 515528.

${ }^{32}$ El poder judicial se pronunció sobre el incumplimiento de las promesas electorales a tenor de la demanda interpuesta por tres particulares y una plataforma contra el PSOE por no haber endurecido las penas contra el maltrato animal como había prometido en su programa electoral de 2008. La Audiencia Provincial de Madrid en el Auto A.P. Madrid 272/2011, de 1 de diciembre sostiene que la "posibilidad de control jurisdiccional de estos márgenes de libertad que exige la acción política, supondría una grave politización de la justicia y, especialmente, una invasión de un poder por otro que vulneraría el principio de separación de poderes”. No estando, en consecuencia, sujetos ni al Derecho civil, ni al Derecho administrativo, los actos consistentes en "promesas electorales ", (sin otra sanción que la responsabilidad política derivada del ejercicio del derecho a voto) no cabe sustanciar una pretensión destinada, desde el principio, al fracaso.

${ }^{33}$ Un interesante estudio sobre los sistemas electorales puede verse en LAGO PEÑAS, I. / LAGO PEÑAS, S., "El sistema electoral español: una cuantificación de sus efectos "mecánico" y "psicológico"”, Revista 
discute la vigencia de la representación como relación de mandante-agente vinculada a un determinado ámbito territorial o se enfatiza la función del representante en la creación y recreación de los intereses y demandas de los representados. En definitiva, los referentes y la metodología utilizados en el estudio de la representación política se están revisando como consecuencia de las transformaciones y nuevos desafíos a los que se enfrenta la sociedad contemporánea, y se reivindican enfoques más próximos y más profundos.

Cabe, por tanto, a tenor de lo expuesto, evidenciar la existencia de dos variables que se relacionan directamente con la representación, por un lado, el tiempo, en tanto en cuanto la representación no debe enfocarse solo desde el momento del voto, sino que debe abrirse a lo largo del mandato parlamentario y por otro lado, la variable espacio, en la que se evidencia el problema de la conexión entre la representación que abarcaría la totalidad de la unidad territorial en la que se celebra la elección -Estado- y la representatividad que se acota a las actuaciones en pro -de modo exclusivo y excluyente- de los intereses de los votantes de una determinada circunscripción electoral ${ }^{34}$.

Idéntica situación se produce en el Parlamento británico. La West Lothian Question surge dentro de los debates sobre la devolution ${ }^{35}$ de competencias a Escocia y hace referencia a las distorsiones que provoca, en una organización territorial claramente asimétrica como es la del Reino Unido, que los diputados escoceses puedan votar e, incluso, determinar la decisión final en cuestiones que solamente afectan a Inglaterra, al tratarse de competencias devueltas a Escocia, mientras que los ingleses no pueden votar cuando se discuten las mismas materias en sede del Parlamento escocés. ${ }^{36}$

El Común Representante de la circunscripción de West Lothian, Tam Dalyell ${ }^{37}$, formulaba en noviembre de 1977 y en sede parlamentaria la siguiente pregunta: "Why can domestic matters affecting England be decided by non-English MPs when English MPs are not able to decide about these matters for Scotland?».

Esta distorsión del parlamentarismo británico que surgía de la devolution se ha puesto de manifiesto en diversas ocasiones en relación a materias especialmente importantes como son las de educación y sanidad, en las que la decisión final sobre la

de Estudios Políticos, n. 107/2000, pp. 225-250. En esta misma línea, Vid. ÁLVAREZ VELEZ, M.I., “El sistema electoral y sus efectos en la formación de mayorías parlamentarias: el sistema electoral del Congreso de los Diputados y de las Comunidades Autónomas”, ÁLVAREZ VÉLEZ, M.I. / ALCÓN YUSTAS, M.F. (Coords.), Estado y Comunidades Autónomas en España, sistemas electorales y participación política, Secretaria General del Senado, Madrid, 2011, pp. 21-54. DELGADO-IRIBARREN GARCÍA-CAMPERO, M., "El sistema electoral español: logros y deficiencias”, KÖLLING, M. (Coord.), Conferencia Los sistemas electorales español y alemán. Un debate de sus efectos, límites y propuestas de reforma, Fundación Manuel Giménez Abad de Estudios Parlamentarios y del Estado Autonómico, Zaragoza, 2012, pp. 13-49.

${ }^{34}$ Se corresponde a la posición de aquellas Comunidades Autónomas que cuentan con partidos políticos de su ámbito territorial con presencia en las Cortes Generales, sin cuyo apoyo no podrían sacarse adelante determinadas iniciativas legislativas.

35 ARONEY, N., Devolutionary Federalism Within a Westminster- derived Context, The Scottish Independence Referendum, Oxford University Press, 2016, pp. 295-323.

${ }^{36}$ MONTALVO JÄÄSKELÄINEN, F., "Multipartidismo territorial y forma de gobierno parlamentaria: la West Lothian Question como paradigma de los efectos del fenómeno”, Revista Española de Derecho Constitucional, n. 115/2015, p. 99.

${ }^{37}$ DALYELL, T., Devolution: the end of Britain?, Cape, London, 1977. 
norma ha dependido del sentido del voto de los Comunes escoceses, cuando se trataba de materias que habían sido devueltas al Parlamento escocés ${ }^{38}$.

Aunque la tendencia sea la ampliación de los términos en los que se desenvuelve el actual concepto de representación política, siempre incluirá, varias dimensiones imprescindibles en una sociedad democrática: la descriptiva (autorización-mandato); la responsabilidad y la receptividad. Sin embargo, debemos ser conscientes de que esa relación representativa no es ni mucho menos estática, sino que es un proceso, cuyo inicio y fin está ligado a las elecciones pero que implica una relación dinámica en la que es preciso incluir alguna forma de participación ciudadana si perseguimos una democracia de calidad.

Así, el concepto de democracia representativa ha sido descrito como un oxímoron entre la democracia que parece referirse al gobierno directo y a la necesidad de canalizar la participación en los Estados con gran número de población.

La búsqueda de un nuevo equilibrio entre participación y representación es la dirección en la que podríamos movernos. No obstante, no tenemos certeza de la relación que existe entre ambos términos, pues no es en absoluto evidente que un aumento cuantitativo en la participación -número de votantes / número de veces que ejercen ese derecho- vaya a traducirse en un incremento análogo en la calidad de la representación. Ni siquiera sabemos si la presencia generalizada de los ciudadanos en todos los momentos del proceso de formación de las decisiones colectivas garantizaría la perfecta representatividad de la voluntad popular ${ }^{39}$.

\section{2. ¿Quién nos representa?: una reflexión desde la teoría de las élites}

Una vez analizados desde una perspectiva descriptiva y someramente las dimensiones de la representación, es preciso realizar una reflexión sobre los sujetos responsables de la representación. Con este objetivo, resulta conveniente ejecutar un breve análisis de los teóricos clásicos de las élites.

La teoría de las élites ${ }^{40}$ es defendida entre otros autores por Sartori ${ }^{41}$, quien considera que, para hablar de élites, o conforme a su definición a las "minorías controlantes, o de poder, se pueden distinguir dos criterios para identificarlas, el primero de ellos, un criterio altimétrico supone que una elite es una minoría que tiene poder, por el simple hecho de lograr hacerse elegir, ya alcanza un poder que la convierte en minoría controlante. El otro de los criterios, supone que esta minoría tenga cualidades tales que se le pueda considerar más capaz o competente.

Sartori era defensor de una "poliarquía electiva”, en la que la democracia se configura sobre tres bases: elección, selección y elites. La elección es el mero hecho de

\footnotetext{
38 Vid. LÓPEZ BASAGUREN, A., "Escocia: El referéndum sobre la independencia de Escocia y la propuesta de reforma de la devolution”, Revista Española de Derecho Constitucional, n. 104/2015, pp. 135167.

${ }^{39}$ GREPPI, A., Teatrocracia. Apología de la representación, Trotta, Madrid, 2016, p. 23.

40 GIMÉNEZ MARTÍNEZ, M.A., "Renovación y continuidad de la élite política española durante la transición a la democracia: el caso de las cortes constituyentes (1977-1979)”, Historia constitucional: Revista Electrónica de Historia Constitucional, n. 15/2014, pp. 255-277.

${ }^{41}$ SARTORI, G., ¿Qué es la democracia?, Taurus, Madrid, 2007, p. 120.
} 
votar, no para seleccionar a los elegidos, sino más bien persiguiendo un interés propio. La selección es simplemente el éxito de una opción.

Otro pensador clave en la teoría elitista de la sociedad es Pareto, quien considera que todo régimen social es siempre aristocrático “dejando por un lado la ficción de la representación popular, y concentrándonos en la sustancia, quitando pocas excepciones de breve duración, siempre hay una clase gobernante poco numerosa que se mantiene en el poder, a veces coactivamente, otras veces con el consentimiento de la clase gobernada mucho más numerosa" 42 .

La teoría de Pareto se basó fundamentalmente en la negación de la existencia real de la democracia y en la defensa de la existencia de una élite dominante. Consideraba que "un régimen en el que el pueblo exprese su voluntad - suponiendo, no concediendo que tenga una- sin clientelas, intrigas ni camarillas, solo existe como puro deseo de teóricos, pero no se observa en las realidades ni del pasado ni en el presente, ni en nuestra tierra ni en otras” ${ }^{43}$. La democracia, en ningún momento ha sufrido una degeneración, sino que nunca ha existido.

Pareto lleva a cabo un análisis de la sociedad centrado en el estudio de los grupos que la componen y la conexión y las relaciones que se establecen entre ellos. Asumiendo la heterogeneidad de la sociedad, observa que dentro de ella existen grupos "que tienen los índices más elevados en el ramo de su actividad”, es decir, grupos que tienen características superiores a los que denomina "las clases selectas", las élites. Conformarían, por tanto, las élites de gobierno aquellos grupos de la clase selecta que tienen una participación notable en el gobierno.

Sobre la base de que los grupos de la sociedad interactúan entre ellos, Pareto analiza el funcionamiento del equilibrio social mediante su teoría de la circulación de las élites, conforme a la cual hay una minoría aristocrática que consigue alcanzar el poder y trata de mantenerlo al menos hasta que una nueva minoría-aristocracia sustituya la anterior, en un movimiento continuo y dinámico; la estrategia para mantener el poder consiste en convencer al pueblo a través de las derivaciones de manera que estas coincidan con las del pueblo. Las derivaciones de la minoría tienen que ajustarse con los sentimientos del pueblo.

Otro de los exponentes de la teoría de las élites es Robert Michels quien defiende que "la democracia no se concibe sin una organización y toda organización requiere una especialización en las tareas, una distinción entre los dirigentes y los dirigidos. El principio de la organización es condición absolutamente esencial para la lucha política de masas" 44 .

Bajo la concepción de este autor, las democracias requieren de un aparato burocrático que, sobre la base de la división del trabajo seleccione unos dirigentes capaces y especializados en determinadas tareas. Si la organización imprescindible para la moderna democracia representativa es el partido político "toda representación partidaria representa un poder oligárquico fundado sobre una base democrática”45.

\footnotetext{
42 PARETO, V., Forma y equilibrios sociales (extracto del Tratado de Sociología General), Alianza Editorial, Madrid, 1980, p. 81.

43 Ibidem, p. 75.

${ }^{44}$ MICHELS, R., Los partidos políticos, Amorrortu Editores España, Buenos Aires, 1993, p.53.

${ }^{45}$ Ibidem, p.58.
} 
Conforme a la teoría de Michels, los líderes del partido político acaban comportándose como "señores" del partido, se identifican con él y tienden a identificar los intereses del partido con sus propios intereses privados cuando en cualquier organización la oligarquía ha alcanzado un estado avanzado de desarrollo, los líderes comienzan a identificar consigo mismo, no solo las instituciones partidarias, sino también la propiedad del partido. Este fenómeno es común tanto en el partido como en el Estado.

A fin de identificar las élites, Putnam estableció una serie de estrategias. En primer lugar, optar por un análisis posicional, que implica que las instituciones de gobierno son un mapa útil de las relaciones de poder y que, por consiguiente, quienes se sitúan en las posiciones más altas de dichas instituciones son los que ostentan más poder político. Una segunda vía de identificación de las élites es el llamado "análisis reputacional”, que prioriza las relaciones informales de poder, dando un protagonismo a la identificación de quién tiene realmente el poder en cada organización. Finalmente, a través del proceso de toma de decisiones en una organización podríamos identificar realmente a las élites, a quien ostenta el poder ${ }^{46}$. Siguiendo todas ellas, nos toparíamos con unas élites integradas por una minoría que tenga cualidades tales que se le pueda considerar más capaz o competente ${ }^{47}$.

A tenor de las teorías clásicas expuestas, introduciremos una reflexión sobre el papel de las élites, en este caso parlamentarias, en la actualidad. Una referencia que comprimiríamos en los siguientes posicionamientos. Las élites serían aquellos que poseen una autoridad formal para dirigir, gestionar y guiar programas, políticas y actividades de las principales instituciones empresariales, gubernamentales, legales, educativas, civiles y culturales en una nación ${ }^{48}$. Compartimos la tesis de la inevitabilidad de las élites ${ }^{49}, \mathrm{y}$ desde este presupuesto analizaremos las desviaciones y los desafíos de las élites del siglo XXI, en particular las élites parlamentarias.

Siguiendo la tesis de Putnam, necesitamos élites y estas han de ser los mejores. Es preciso depurar tres preocupaciones que surgen en torno a las élites, especialmente en Estados descentralizados. La primera de ellas es la necesidad de depurar a quiénes realmente tienen el poder y toman las decisiones, estos pueden coincidir o no con quien formalmente se identifica como titular de un órgano de poder y por ello es un elemento a valorar. Un segundo dato, es la conexión entre élites, las influencias tenidas o perseguidas por las élites para afianzarse en esa posición y, a su vez, para fortalecerla. En este punto, hay que recoger el guante de la historia más reciente de España en la que se verifica la tendencia a la no renovación de las élites y a su escasa permeabilidad ${ }^{50}$. El dato del surgimiento de nuevos partidos, con sus nuevas élites, hay que incorporarlo al discurso, dado que estas nuevas élites externamente parecen quebrar estos presupuestos, pero internamente son fieles a los patrones más tradicionales.

\footnotetext{
${ }^{46}$ PUTNAM, R.E., The comparative study of political elites, Prentice Hall, New Jersey ,1976, p. 177.

47 SARTORI, G., ¿Qué es la democracia?, Taurus, Madrid, 2007, p. 120.

${ }^{48}$ DYE, T.R., Who is running America, Prentice Hall, New Jersey, 1976, p.12.

49 URIARTE BENGOETXEA, E., "El análisis de las élites políticas en las democracias”, Revista de Estudios Políticos, n. 97/1997, p. 254.

${ }^{50}$ DEL CAMPO URBANO, S. / TEZANOS TORTAJADA, J.F. / SANTÍN, W., "La élite política española y la transición a la democracia”, Sistema: Revista de ciencias sociales, n. 48/1982, p. 51.
} 
La tercera es cómo esas élites interactúan con los ciudadanos, especialmente en los momentos de tensión política y en los períodos de grandes crisis ${ }^{51}$. Nos podemos encontrar una serie de perfiles bien diferenciados, pero que podemos reconducir a dos, los líderes que recogen las peticiones de los ciudadanos y las formulan o reformulan, pero manteniendo la esencia de las mismas. A partir de ahí las canalizan y buscan su satisfacción, sin renunciar a poner su impronta y a recibir su compensación, en réditos electorales. Por otro lado, hemos de identificar a aquellas élites que persiguen afianzarse a costa de crear problemas y necesidades o aspiraciones en los ciudadanos. Ese proceso es lento y minucioso y puede exigir la cooperación de muchas entidades sociales y políticas, tiene que estar articulado en torno a un plan ordenado y ha de poseer además de una vis atractiva desde el mensaje en sí, un elemento subjetivo de captación o abducción, en función del grado de convencimiento y adscripción de los ciudadanos, y un alter externo cuya negatividad y a cuyo enfrentamiento se va a derivar, a sensu contrario, el fortalecimiento interno y la compactación del proyecto. Esta es la gran paradoja y el gran reto de la capacidad formativa de los parlamentos.

Desde estos asertos generales, nuestra postura es meridianamente clara y contrastable. Las élites políticas se distancian de ese ideal de ser los mejores, y frente a esas capacidades brillantes han priorizado habilidades y competencias "populísticas” que parecen ser efectivas, tanto a nivel estatal, autonómico, como internacional. En conclusión, las élites ya no son los mejores, pero bloquean el acceso a los mejores y se autoalimentan desde la satisfacción ejemplar de necesidades que ellos mismos han contribuido a crear. Esas aptitudes son todo lo contrario a lo que necesitamos para solventar problemas y para liderar el trabajo de las instituciones, en particular el Parlamento.

\section{La contradicción de la representación política: una perspectiva histórica}

Desde una perspectiva doctrinal clásica, y de manera breve por la excesiva amplitud del tema que nos ocupa, trataremos de ofrecer una síntesis de las principales aportaciones de una selección de autores clásicos ${ }^{52}$ a la teoría de la representación ${ }^{53}$.

Antes de ahondar en las distintas teorías, es preciso tener en cuenta la concepción de la representación en el discurso medieval porque en ella insertaremos la referencia

\footnotetext{
${ }^{51}$ La crisis económica ha convertido en insoportables las deficiencias del sistema representativo. En tiempos de bonanza se pasan por alto, pero eso resulta más difícil cuando el sistema no ofrece respuesta para los graves problemas cotidianos. Se reclaman entonces no sólo otros resultados u otras políticas, sino también otras formas políticas: una democracia real que supere los límites de la democracia representativa de partidos, Vid, a este respecto: GUTIÉRREZ GUTIÉRREZ, I., La democracia indignada. Tensiones entre voluntad popular y representación política, Comares, Granada, 2015.

${ }^{52}$ Vid. DE VEGA, P., "Significado constitucional de la representación política", Revista de Estudios Políticos (Nueva Época), n. 44/1985, pp. 25-45.

${ }^{53}$ Algunos autores han vinculado los postulados de la teoría de la representación con los principios básicos del cristianismo. Así, afirman que conceptos cristianos como la Alianza de los hombres con Dios o el Libro Sagrado encuentran figuras muy similares con el Contrato Social y en la Constitución propia de cualquier democracia, siendo significativo el hecho de que la evolución de la democracia representativa, propiciada por la democracia participativa, es salvando las distancias, similar a la evolución o reforma que el cristianismo sufrió en el siglo XVI, pudiéndose ver en ambos casos un intento de relacionar sin intermediarios al hombre ya con su Soberanía ya con Dios. RAMÍREZ NÁRDIZ, A., Democracia participativa. La experiencia española contemporánea, Universidad de Alicante, Alicante, 2009, p. 46.
} 
histórica al origen del parlamentarismo. Esta visión presupone la existencia de un orden ya dado ${ }^{54}$, intrínsecamente legítimo, la imagen de un pueblo estructurado y organizado jerárquicamente apuntalado en las imágenes de jerarquía y de corpus, en el que soberanía recaía en la figura del Monarca.

Los Parlamentos medievales no tienen parte en el Estado. Eran Cámaras externas sin voz ni voto en el ejercicio del poder. Tampoco eran Cámaras electas, su naturaleza representativa procedía de la estructura corporativa de la sociedad medieval ${ }^{55}$.

A lo largo de los siglos XVII y XVIII se va debilitando paulatinamente la concepción medieval de la representación que entra definitivamente en crisis tan pronto como decae la visión antropológica y política que la sostenía y se produce un desarrollo de un nuevo paradigma basado en la individualidad ${ }^{56}$.

Será en el trascurso de los siglos XIX y XX cuando el Estado deje de ser el Rey en solitario para ser el Rey en el Parlamento, lo que implica que el Parlamento entra a formar parte del Estado. Los gobiernos representativos modernos, en consonancia con las sendas trazadas por el inglés y el francés, se constituyeron sobre la premisa de que los representantes no eran, ni debían ser, delegados vinculados a instrucciones imperativas. De hecho, la expresión "voluntad nacional” y "cada miembro del Parlamento representa a la Nación y ejerce sus funciones sin estar sujeto a mandatos" son fórmulas bastantes comunes que aparecen prácticamente en todas las Constituciones europeas de los siglos XIX y XX.

En el contexto de los siglos XVII y XVIII emerge la teoría de Hobbes ${ }^{57}$, quien enfoca la representación ${ }^{58}$ como condición de existencia de la soberanía nacional. Toda la construcción liberal de la soberanía adopta, en el fondo, el formato de una pura cuestión de teoría de la representación; o, lo que es lo mismo, que todo el dilema histórico que en aquel momento está planteado se resuelve -sustitución de la "representación absortiva" del Monarca por la "representación electiva” del Parlamento- como un mero problema de sucesión o sustitución en los esquemas representativos que están en la base del Estado. El orden es el efecto de una decisión concordante de los sujetos, dispuestos a concentrar en el soberano la totalidad del poder.

\footnotetext{
54 "La realidad misma se considera esencialmente ordenada: el ser está compuesto de entes ontológicamente diferenciados y jerárquicamente alineados. Dios, los ángeles, los hombres, los seres animados; el emperador, el vasallo, el siervo, son diferentes peldaños de una misma pirámide: tanto el cosmos como la sociedad humana subsisten en la medida en que están alineados según una estructura desigual y jerárquica que culmina en un vértice”. COSTA, P., "El problema de la representación política: una perspectiva histórica”, Anuario de la Facultad de Derecho de la Universidad Autónoma de Madrid, n.8/2004, p. 17. 55 SARTORI, G., “En defensa de la representación política”, Claves de la Razón Práctica, n. 91/1999, pp. 2-6.

${ }^{56}$ Sobre algunas cuestiones relativas a estos precedentes teóricos, Vid.: PORTERO MOLINA, J.A., "Sobre la representación política”, Revista del Centro de Estudios Constitucionales, n. 10/1991, pp. 89-119.

57 "Una multitud se convierte en persona cuando es representada, porque es la unidad del representante y no la unidad del representado la que hace a la unidad de esa persona”. HOBBES, T., Leviathan, Alianza Editorial, Madrid, 2004, p. 130.

${ }^{58}$ Conforme a la teoría de Hobbes, la representación implica, en efecto, un desdoblamiento: un sujeto actúa por otro en cuanto autorizado por este último. La representación es la relación entre un autor que no actúa, pero concede sus propias palabras y acciones a otro, y este último, el actor, que actúa en lugar de aquel. El contrato social se solventa en una seria de autorizaciones convergentes en la creación de un soberano que, en consecuencia, puede decirse esencialmente representativo.
} 
Hobbes está considerado como un teórico del absolutismo y no de la representación, pero lo cierto es que esta desempeña un lugar central en el Leviatán, en cuanto significaba la superación del concepto medieval sobre la misma, si bien, por otra parte, negaba, la futura construcción liberal representativa.

El elemento moderno de la formulación de Hobbes reside en que ya no existen, según la idea medieval, sujetos singularizados, es decir, los estamentos, sino que ahora solo hay masas, incapaces de organizarse a sí mismas -el orden no es una estructura de la realidad, no está garantizado por la naturaleza de las cosas, sino que debe ser inventado, construido-. Estas conceden su representación como unidad al soberano, quien, por tanto, es un representante autorizado o designado por la multitud para que ejerza el poder ${ }^{59}$. Justamente este ejercicio del poder es el que niega y se contrapone al que después sería el concepto liberal de la representación, puesto que el soberano no tiene límites temporales ni materiales en su actuación ni se le puede exigir responsabilidades. Se entiende, en definitiva, que la representación es la voluntad del soberano representante que ha producido la unidad del pueblo.

Otra de las respuestas a la teoría de la representación es la defendida por Montesquieu ${ }^{60}$ para el que la gran ventaja de los representantes frente a los representados es que son capaces de discutir los asuntos. El pueblo en modo alguno lo es, lo que constituye uno de los graves inconvenientes de la democracia (...) por eso el pueblo no debe entrar en el gobierno más que para elegir a sus representantes, lo que está muy a su alcance, pero la facultad legislativa será confiada al cuerpo que se elija para representar al pueblo" 61 .

Montesquieu junto con Sieyés son los exponentes clásicos de la teoría francesa sobre la representación. Ambos sostienen la libertad e independencia de los representantes elegidos para tomar iniciativas y discutir los asuntos públicos, si bien, sobre todo Sieyés formula más acabadamente la vinculación representativa con la doctrina burguesa de la soberanía nacional. Como quiera que la nación la forman solo los ciudadanos, o sea, el Tercer Estado -excluidos los estamentos privilegiados-, los diputados o representantes, en tanto que miembros de la Asamblea representan y expresan la voluntad no de sus electores concretos -por medio del sufragio restringido-, sino de toda la nación como colectividad. Desde estos presupuestos se desprenden dos consecuencias de máximo interés. La primera reside en que, al predicarse la totalidad y homogeneidad de la nación, esta se entiende formada por individuos y la representación tiene un carácter individualista, sin que quepa la formación de grupos intermedios o partidos en la Asamblea. Con esto se pretendía evitar, en aquella época, más bien la creación de cuerpos aristocráticos. La otra consecuencia es que, si bien se afirma que los representantes manifiestan en la Asamblea la voluntad de la nación, como esta no tiene

\footnotetext{
59 “Transferir todo el poder y toda la fuerza a un hombre o una asamblea de hombres” (Hobbes), esto es, a una institución que monopoliza el poder político y que se puede articular ora como República, ora como Monarquía. MAÍZ SUÁREZ, R., "El Dios mortal ¿implica la globalización una progresiva desaparición del Estado?”, Araucaria: Revista Iberoamericana de filosofía, política y humanidades, vol. 19, núm. 37, 2017, p.7.

${ }^{60}$ Vid. TOUCHARD, J., Historia de las ideas políticas, Tecnos, Madrid, 1990, p. 313.

${ }^{61}$ MONTESQUIEU, CH. L., El espíritu de las leyes, Alianza Editorial, Madrid, 2015, pp. 545-697.
} 
por sí misma voluntad, en realidad son los representantes los que constituyen y crean libremente esa voluntad que antes no existía ${ }^{62}$.

La constitución representativa es el modo de que la inteligencia y honradez, difundidas en la sociedad, así como el entendimiento y la virtud de los hombres superiores, pese más directamente sobre el Gobierno, es la manera de darles más influencia que la que tendrían en cualquier otro sistema. A decir verdad, lo que de esta influencia exista en todo Gobierno, cualquiera que sea su organización, es la fuente de todo bien que en él hay y el obstáculo al mal de que carece. Cuanto mayor sea la suma de buenas cualidades que las instituciones de un país logren organizar y más excelente el modo de su organización, tanto mejor será el Gobierno ${ }^{63}$.

La elección de un representante remite a una doble lógica de distinción e identificación ${ }^{64}$. Se pretende que aquel por quien se vota tenga la capacidad para gobernar. La opción es guiada por el reconocimiento de las cualidades como dirigente y de las competencias técnicas del candidato. La elección obedece, entonces, a un principio de distinción. Se apoya en la idea de que es preciso seleccionar a los mejores, y el elector admite de manera implícita que el elegido tiene capacidades que el mismo no posee. Pero simultáneamente se espera del representante que se mantenga cercano a sus electores, que conozca sus problemas y preocupaciones, que comparta sus inquietudes y aspiraciones. En este caso, la elección se refiere a un principio de proximidad, de identidad. El representante ideal es, desde esta perspectiva, el que piensa, habla y vive como sus mandantes, como especie de doble valorizado por ellos. Por un lado, la esperanza de que los elegidos sean competentes; por el otro, la aspiración de que sean, ante todo, semejantes ${ }^{65}$.

Según Rousseau, el pueblo debe reunirse en una especie de asamblea constituyente en la cual los individuos son convocados como libres e iguales a participar en una deliberación para darle una constitución a su sociedad política. Para Rousseau, el pueblo como verdadero soberano, dotado del poder absoluto, es el origen de todo. Solo el pueblo puede dictar leyes para sí mismo, puede constituir el Estado. "La soberanía es inalienable, indivisible $\mathrm{e}$ infalible $\mathrm{y}$ no puede manifestarse por medio del mecanismo representativo" 66 .

El propio Rousseau es consciente de que en el Estado Moderno la democracia directa es imposible, y que la elección de representantes se convierte en un mal necesario, que como tal hay que aceptar. Pero no es menos cierto que, para proteger la parcela de soberanía irrenunciable de cada ciudadano, Rousseau somete la actuación de los representantes a dos condiciones inexcusables. En primer lugar, que los elegidos no tengan un poder propio, de suerte que solo puedan hacer lo que expresamente el pueblo les permita -mandato imperativo-. "Los diputados del pueblo no son sus representantes; solo son sus comisarios”. En segundo término, que lo que los elegidos decidan, debe ser

\footnotetext{
62 ABELLÁN GARCÍA, A.M., "Notas sobre la evolución histórica del Parlamento y la representación política”, Revista de Estudios Políticos, n. 92/1996, p. 168.

63 A tenor de esta argumentación, Montesquieu defiende la teoría de las élites que ha sido abordada a grandes rasgos con anterioridad.

${ }^{64}$ Vid. al respecto, RIDAURA MARTÍNEZ, M.J., Representación política y parlamentarismo multinivel, Tirant lo Blanch, Valencia, 2014.

65 ROSANVALLON, P., La legitimidad democrática. Imparcialidad, reflexividad y proximidad, Paidós, Barcelona, 2008, p. 253.

${ }^{66}$ ROUSSEAU, J.J., El contrato social o principios de derecho político, Tecnos, Madrid, 2007.
} 
siempre ratificado por el pueblo. "Toda ley que no haya sido ratificada por el pueblo en persona es nula: no es una ley" ${ }^{67}$.

La auténtica necesidad del modelo representativo burgués fue doctrinal y políticamente puesta de manifiesto por Edmund Burke en su famoso Dircurso a los Electores de Bristol en $1744^{68}$. En este discurso, Burke avanzaba un grado más en el concepto de representación al argumentar no solo que el representante debía deliberar y actuar con independencia y según su libre juicio en el interés general de la nación, sino que esto había de ser así porque la legislación y el gobierno son cuestiones de juicio y de razón al alcance únicamente de la altura moral y formativa de los elegidos.

Afirma que los representantes manifiestan en la Asamblea la voluntad de la nación, como esta no tiene por sí misma voluntad, en realidad son los representantes los que constituyen y crean libremente esa voluntad que antes no existía ${ }^{69}$.

Para Burke, la representación parlamentaria debe estar desvinculada del condicionamiento de los electores particulares. El Parlamento mira a la totalidad de la nación y encuentra su fundamento en el orden jurídico, no en los sujetos y en sus inmediatas e inconexas voluntades, sino en la trama objetiva de una constitución que se desarrolla incesantemente a través que pequeños ajustes progresivos ${ }^{70}$.

Burke parecía tener en mente una exigencia que continúa presente en el discurso moderno de la representación ${ }^{71}$, la exigencia de que el desdoblamiento entre los individuos particulares y el sujeto colectivo nación, no se traduzca en un déficit de representatividad de la institución representativa ${ }^{72}$. Si ello sucediera, se impediría a los primeros reconocerse en los segundos, se bloquearía todo mecanismo de identificación, con el resultado de malograr las valencias legitimantes del mecanismo representativo; y es en este sentido en el que Burke habla de la importancia de sentirse representado, de la necesidad de actuar de manera tal que la representación pueda dar lugar también a una "communion of interest and sympath in feelings and desires". ${ }^{73}$

\footnotetext{
${ }^{67}$ DE VEGA, P., “Legitimidad y representación en la crisis de la democracia actual”, Institut de Ciencies Politiques i Socials, Barcelona, 1998, versión on-line.

68 "El Parlamento no es un congreso de embajadores que defienden intereses distintos y hostiles, intereses que cada uno de sus miembros debe sostener, como agente y abogado, contra otros agentes y abogados, sino una asamblea deliberante de una nación, con un interés: el de la totalidad; donde deben guiar no los intereses y prejuicios locales, sino el bien general que resulta de la razón general del todo. Elegís un diputado; pero cuando lo habéis escogido, no es el diputado por Bristol, sino un miembro del Parlamento”. BURKE, E.: Discurso a los electores de Bristol al ser declarado, por los sheriffs, debidamente elegido como uno de los representantes de aquella ciudad en el Parlamento, el jueves día 3 de noviembre de 1774.

69 ABELLÁN GARCÍA, A.M., "Notas sobre la evolución histórica del Parlamento y la representación política”, Revista de Estudios Políticos, n. 92/1996, p. 168.

${ }^{70}$ COSTA, P., "El problema de la representación política: una perspectiva histórica”, Anuario de la Facultad de Derecho de la Universidad Autónoma de Madrid, n.8/2004, p. 23.

${ }^{71}$ Entre las aportaciones recientes a la Teoría de la representación, Vid. ABELLÁN ARTACHO, P., "Representación política y democracia. Aportaciones desde la Teoría de la Representación en los últimos diez años”, Revista Española de Ciencia Política, n. 33/2013, pp. 133-147.

72 Es referencia común decir que el Parlamento es la institución representativa. Con ello se quiere indicar que un grupo reducido de personas "representan" al conjunto de los ciudadanos porque son la expresión de la voluntad de ese pueblo manifestada en sede parlamentaria. ALONSO DE ANTONIO, J.A. / ALONSO DE ANTONIO, A.L., Derecho Parlamentario, J.M. Bosch Editor, Barcelona, 2000, p. 12.

${ }^{73}$ FENICHEL PITKIN, H., El concepto de representación, Centro de Estudios Políticos y Constitucionales, Madrid, 2014, p. 184.
} 
En resumen, Burke concebía el gobierno parlamentario como dirigido por una minoría compacta, pero que buscaba el bien público, a la que en general el país estaba dispuesto a seguir, y en la cual el Parlamento era ante todo un lugar donde se podía criticar a los líderes de esa minoría y donde su partido podía exigirles responsabilidad, pero en interés de todo el país ${ }^{74}$.

Se estima necesario en todo estudio relacionado con la teoría de la representación hacer referencia a la obra de Condorcet ${ }^{75}$ que abogó, en un principio, por defender la existencia de una serie de restricciones en el derecho al voto, superadas tras la Revolución, momento en el cual acepta el sufragio universal e incluso la posibilidad de determinadas formas de participación directa, en concreto las consultas populares para la aprobación de las declaraciones de derechos y de las Constituciones. Condorcet señala que la soberanía es única e inalienable y que reside en el pueblo, por lo que el verdadero poder legislativo es el del pueblo y la Asamblea solo ejerce una función delegada por este, el cual delega esta función, pero no abdica de ella, por lo que puede revocársela a la Asamblea mediante expresa declaración ${ }^{76}$. La evolución del pensamiento de Condorcet llega al punto de considerar que el pueblo no se desprende por completo de su poder, sino que se reserva determinadas facultades.

Cabe destacar, asimismo, la obra de Constant quien sostenía que el "sistema representativo no es otra cosa que una organización con cuya ayuda una nación descarga en algunos individuos lo que ella no puede o no quiere hacer por sí misma"77. Este autor concebía la representación como una necesidad del burgués para disponer de tiempo para sus asuntos privados. La representación es la única técnica de participación política que conviene o se adecúa al modo de ser presente de la libertad, esto es, a la libertad de los modernos. Es en su obra "Escritos políticos"78 en la que acuña esta expresión en contraposición a la "libertad de los antiguos". Este nuevo paradigma de libertad presupone una especie de independencia del individuo en relación a los asuntos públicos. Mientras los antiguos reclamaban para sí una participación continua en los asuntos públicos como medio de legitimación del sistema político, los liberales modernos abogaron por limitar la participación a la selección y remoción de los representantes públicos a través de unas elecciones periódicas entendidas como garantía de control de la actuación de los representantes y de la contención de posibles abusos ${ }^{79}$.

Conforme a la argumentación de Constant, la Historia ha producido una mutación sustancial en las condiciones del problema y a ello debemos de atenernos. "Los progresos

\footnotetext{
${ }^{74}$ SABINE G., Historia de la teoría política, Fondo de Cultura Económica, Madrid, 1993, p. 448.

${ }^{75}$ Condorcet es considerado por una parte de la doctrina como el primer pensador que usa la expresión democracia representativa, y, por tanto, el creador del concepto democracia representativa.

${ }^{76}$ CONDORCET, J.M., Bosquejo de un cuadro histórico de los progresos del espíritu humano, Editorial Nacional, Madrid, 1980, p.46.

${ }^{77}$ Desde la perspectiva de la libertad que a nosotros nos interesa, mientras más tiempo libre nos deje el ejercicio de los derechos políticos para dedicarnos a nuestros intereses privados, más preciosa nos será esa misma libertad". CONSTANT, B., Collection complète des ouvrages publiés sur le Gouvernement représentatif et la Constitution actuelle, ou Cours de Politique Constitutionnelle, vol. 4, Librairie de Guillaumin, Paris, 1980, p. 238.

${ }^{78}$ CONSTANT, B./ SÁNCHEZ MEJÍA RODRÍGUEZ, M.L., Escritos Políticos, Centro de Estudios Políticos y Constitucionales, Madrid, 1989.

${ }^{79}$ ALMAGRO CASTRO, D., "La participación política en la teoría democrática: de la modernidad al siglo XXI”, Revista de Estudios Políticos, n. 174/2016, p. 175.
} 
de la civilización, la tendencia comercial de la época, la comunicación de los pueblos, han multiplicado y variado hasta el infinito las formas del bienestar particular" ${ }^{80}$. Lo que ha sucedido es que la moderna civilización ha generado una multiplicación total de las posibilidades de bienestar particular, y es la preferencia del burgués por tales posibilidades la que ha determinado cómo vamos a pasar a entender desde ese momento nuestra libertad.

En último lugar, es preciso hacer referencia a la obra de Sieyès ${ }^{81}$ quien enfoca la representación como forma de división del trabajo. La argumentación de Sieyès toma como punto de origen a Burke y sus alusiones al superior criterio de las representantes contenidas en el Discurso a los electores de Bristol y fundamentalmente, por la afirmación de Montesquieu conforme a la cual la gran ventaja de los representantes es que ellos tienen la capacidad para discutir los asuntos, el pueblo no es en absoluto apropiado para ello.

El nexo de conexión para Sieyés era evidente: si en todos los terrenos de la vida social se va a acrecentar la calidad de los resultados mediante el recurso a la división del trabajo ¿por qué no operar de igual manera en la vida política? ¿Por qué no elevar también en ella la calidad del producto acudiendo a la división del trabajo, esto es, recurriendo a personas particularmente preparadas o especializadas para el mejor cumplimiento de esa tarea? No tendría ningún sentido que, en un mundo que aplica esta técnica a todos los sectores y entiende que tiene en ella una de las claves de la modernidad y el progreso, la política la abandonara; hagamos también recurso, pues, en política al especialista, esto es, al representante, concebido como experto al que trasladar este sector de actividad.

Para Sieyés, la representación lejos de ser una mala alternativa a la democracia es su única realización posible. La democracia es, en efecto, la atribución del poder soberano al peuple en corps. Pero la nación como tal, en las complejas sociedades del presente, no puede existir en corps: solo en la asamblea representativa será posible localizar aquella concurrencia física de los miembros del cuerpo soberano que había caracterizado a la antigua ágora.

Entre los requisitos que Sieyés esgrime en su defensa de la necesidad de nombrar representantes, cabe reparar en dos referentes especialmente recuperables en los actuales cuestionamientos de los sistemas representativos ${ }^{82}$. Apelaba Sieyés a que la gran pluralidad de los ciudadanos, esto es, sobre un condicionante cuantitativo, que pudiéramos en un futurible más o menos próximo compensar de la mano de las nuevas tecnologías, de dos condicionantes cualitativos que postraban la aspiración ciudadana de dirigir los asuntos de Estado de un modo directo, se refería a la ausencia de preparación, de instrucción, y a la circunstancia de no disponer de momentos de ocio para ocuparse directamente de las leyes que han de gobernar.

\footnotetext{
${ }^{80}$ CONSTANT, op. cit. p. 254.

81 "La conveniencia común justifica que los ciudadanos nombren representantes mucho más capaces que ellos de conocer su interés y de interpretar su voluntad. La gran mayoría de los ciudadanos carece de preparación para ocuparse de las leyes que deben gobernar Francia”. KOUNG, Y., Théorie constitutionnelle de Sieyès, París, 1934, pp. 67-68.

82 SEIJAS VILLADANGOS, Mª . E., "Los gobiernos de los Estados de la Unión Europea”, MATIA PORTILLA, F.J. (Coord.), Pluralidad territorial, nuevos derechos y garantías, Comares, Granada, 2012, pp. 117-145.
} 
En resumidas cuentas, la formación teórica del Parlamento es un agregado de concepciones en las que prima la idea deliberativa e institucional, desde esa acepción orgánica se proyectarán distintos requerimientos, en particular, que se conecte a la ciudadanía, que sea elegido y por tanto democrático. Por consiguiente, en sociedades grandes y complejas, con intereses e ideas plurales, la democracia viable es la democracia representativa, con pesos y contrapesos entre los diferentes poderes del Estado.

\section{A MODO DE CONCLUSIÓN}

La concepción clásica de la representación estudiada a lo largo de estas líneas, tomando como base la teoría clásica de Pitkin, se constituye en la esencia de la conciliación entre instituciones e individuos de tal forma que se comprometan en la consecución del interés público, en la genuina traslación de la voluntad de los ciudadanos y, al mismo tiempo, en la implementación de una férrea convicción para seguir sosteniendo una actitud crítica con tales instituciones y con tales aprendizajes con el fin de que siempre nos mostremos abiertos a posteriores interpretaciones y reformas.

La conceptualización de la representación ha llevado a distinguirla en su implementación de la representatividad. De ambos conceptos depende la comprensión de la política representativa, pero no son equivalentes. La representatividad se engloba dentro de la dimensión de la representación, vinculada con la acepción de representación como correspondencia, descripción o reflejo. Alude, en este sentido, a las características funcionales o sociodemográficas identificativas comunes a los representantes y los representados. Esta matización tiene interesantes consecuencias en aspectos incidentales como el transfuguismo.

La representación está íntimamente relacionada con la noción de autoridad; de modo diferenciado, la representatividad encuentra su base en el consentimiento, en la consonancia que se establece entre gobernantes y gobernados cuando los primeros consiguen traducir en fórmulas jurídicas valores que se manifiestan de forma preeminente en la sociedad gobernada.

Desde esta perspectiva, adquiere especial importancia cuestionarse quién nos representa. Atendiendo a la teoría de las élites y trasladable a las élites parlamentarias del siglo XXI, la postura es meridianamente clara. Necesitamos élites y estas han de ser las mejores. Las élites políticas, entendidas como aquellas que lideran las instituciones de gobierno de un Estado en todos y cada uno de sus niveles organizativos, son inevitables. En la actualidad, las élites políticas se distancian de ese ideal y frente a esas capacidades brillantes han priorizado habilidades y competencias "populistas" que parecen ser efectivas, tanto a nivel estatal, autonómico, como internacional. En conclusión, las élites ya no son las mejores, pero coadyuvan a bloquear el acceso a los mejores y se autoalimentan desde la satisfacción ejemplar de necesidades que ellos mismos han contribuido a crear. Esas aptitudes son todo lo contrario a lo que necesitamos para solventar problemas y para liderar el trabajo de las instituciones, en particular el Parlamento.

Bajo esa constatación, se propone una reconstrucción de la teoría de las élites, aclimatada a un momento de crisis, cuya causa y cuyo efecto parece apuntar a un mismo sujeto, las élites. 
Partiendo de esta afirmación, es conveniente filtrar tres preocupaciones que surgen en torno a las élites. La primera de ellas es la necesidad de depurar a quienes realmente tienen el poder y toman las decisiones, estos pueden coincidir o no con quien formalmente se identifica como titular de un órgano de poder y por ello es un elemento que valorar. Un segundo dato, es la conexión entre élites, las influencias tenidas o perseguidas por estas para afianzarse en esa posición y, a su vez, para fortalecerla. En este punto, hay que tomar en consideración la realidad histórica más reciente de España en la que se constata la tendencia a la no renovación de las élites y a su escasa permeabilidad. La tercera es cómo esas élites interactúan con los ciudadanos, especialmente en los momentos de tensión política y de grandes crisis.

En este sentido, podemos encontrarnos una serie de perfiles diferenciados, pero que podemos reconducir a dos, los líderes que recogen las peticiones de los ciudadanos y las formulan o reformulan, pero manteniendo la esencia de las mismas. A partir de ahí las canalizan y buscan su satisfacción, sin renunciar a poner su impronta y a recibir su compensación, en réditos electorales. Por otro lado, hemos de identificar a aquellas élites que persiguen afianzarse a costa de crear problemas y necesidades o aspiraciones en los ciudadanos.

A partir de ahí, surge el interrogante sobre qué estrategias procede aplicar. Es evidenciable la existencia de dos factores que influyen directamente en el comportamiento estratégico de las élites. Por un lado, los medios de comunicación, como formadores de la opinión pública, que desempeñan un papel decisivo. La prensa, y especialmente los criterios con los que da cobertura a los mensajes y la decisión de qué es noticia fomentan la "personalización” de la información. Por ello se propone velar por una información accesible, veraz y de calidad en donde las propias instituciones públicas deben poner al servicio de la ciudadanía datos relevantes, presentados de manera comprensible e interesante. De esta forma se harán más útiles, y se evitará el posible sesgo o distorsión del mensaje original para la obtención de rédito político.

El carácter descentralizado del Estado español conlleva la existencia de una proliferación de élites. Estrechamente vinculado con este extremo, florece la necesidad de potenciar la educación, desde y hacia las élites. En España hemos asistido a un profundo cambio en la designación de las élites, en la XI y XII Legislaturas. Este hecho es positivo per se, sin embargo, lo que resta por verificar es que estas nuevas élites puedan liderar un proceso de reversión de las élites, es decir la recuperación de estas para los más capacitados a ejercer el liderazgo político.

Con esta reflexión, no cabe entender que se abogue por la presencia de burócratas o técnicos, ni del retorno de las tecnocracias, sino por la existencia de unas elites políticas, democráticamente elegidas, responsables, coherentes, con aptitudes de gestión, liderazgo y profundos conocimientos de la dinámica estatal. 


\section{REFERENCIAS BIBLIOGRÁFICAS}

ABELLÁN ARTACHO, P., "Representación política y democracia. Aportaciones desde la Teoría de la Representación en los últimos diez años”, Revista Española de Ciencia Política, n. 33/2013, pp. 133-147.

ABELLÁN GARCÍA, A.M., "Notas sobre la evolución histórica del Parlamento y la representación política”, Revista de Estudios Políticos, n. 92/1996, pp. 163-165.

ABELLÁN LÓPEZ, M ${ }^{\mathrm{a}}$ A., "El sistema de control externo multinivel español: Rendición de cuentas, desafíos y oportunidades”, Revista Cuadernos Manuel Giménez Abad, n. 13/2017, pp. 51-65.

ALMAGRO CASTRO, D., “La participación política en la teoría democrática: de la modernidad al siglo XXI”, Revista de Estudios Políticos, n. 174/2016, pp. 173-193.

ALONSO DE ANTONIO, J.A. / ALONSO DE ANTONIO, A.L., Derecho Parlamentario, J.M. Bosch Editor, Barcelona, 2000.

ÁLVAREZ VELEZ, M.I., "El sistema electoral y sus efectos en la formación de mayorías parlamentarias: el sistema electoral del Congreso de los Diputados y de las Comunidades Autónomas", ÁLVAREZ VÉLEZ, M.I. / ALCÓN YUSTAS, M.F. (Coords.), Estado y Comunidades Autónomas en España, sistemas electorales y participación política, Secretaria General del Senado, Madrid, 2011, pp. 21-54.

ARCE JANÁRIZ, A., “Tránsfugas y portavoces en el Grupo Mixto (Dictamen sobre la constitucionalidad de la portavocía del Grupo Parlamentario Mixto preparada por el grupo de trabajo para la reforma del Reglamento de la Junta General del Principado de Asturias)”, Revista de las Cortes Generales, n. 40/1997, pp. 155-170.

ARONEY, N., Devolutionary Federalism Within a Westminster- derived Context, The Scottish Independence Referendum, Oxford University Press, 2016.

BELMONTE MARTÍN, I., "De la opacidad a la cultura de la transparencia y de la rendición de cuentas. Una aproximación a la visibilización de los lobbies para la regeneración democrática”, CALABUIG PUIG, Ma.A. / SANJUÁN ANDRÉS, F.J. (Coords.) / TUR AUSINA, R. (Dir.), Poderes públicos y privados ante la regeneración constitucional democrática, Dykinson, Madrid, 2016, pp. 251-265.

BURKE, E.: Discurso a los electores de Bristol al ser declarado, por los sheriffs, debidamente elegido como uno de los representantes de aquella ciudad en el Parlamento, el jueves día 3 de noviembre de 1774.

BUSTOS GISBERT, R., Calidad democrática, Marcial Pons, Valencia, 2016.

CEBRIÁN ZAZURCA, E., Sobre la democracia representativa. Un análisis de sus capacidades e insuficiencias, Universidad de Zaragoza, Zaragoza, 2013.

CONDORCET, J.M., Bosquejo de un cuadro histórico de los progresos del espíritu humano, Editorial Nacional, Madrid, 1980.

CONSTANT, B., Collection complète des ouvrages publiés sur le Gouvernement représentatif et la Constitution actuelle, ou Cours de Politique Constitutionnelle, vol. 4, Librairie de Guillaumin, Paris, 1980.

CONSTANT, B./ SÁNCHEZ MEJÍA RODRÍGUEZ, M.L., Escritos Políticos, Centro de Estudios Políticos y Constitucionales, Madrid, 1989.

Revista de Estudios Jurídicos no 18/2018 (Segunda Época)

ISSN-e 2340-5066. Universidad de Jaén (España)

Versión electrónica: rej.ujaen.es 
COSTA, P., "El problema de la representación política: una perspectiva histórica”, Anuario de la Facultad de Derecho de la Universidad Autónoma de Madrid, n.8/2004, pp. 15-62.

CRIADO DE DIEGO, M., Participar. La ciudadanía activa en las relaciones estado sociedad, Dykinson, Madrid, 2014.

DALYELL, T., Devolution: the end of Britain?, Cape, London, 1977.

DE LA FUENTE Y DE LA CALLE, $M^{\mathrm{a}} \mathrm{J}$., "Reflexiones acerca de la transparencia como instrumento de mejora de la gestión pública, Revista española de control externo, n. 56/2017, pp. 43-75.

DE VEGA, P., "Legitimidad y representación en la crisis de la democracia actual”, Institut de Ciencies Politiques i Socials, Barcelona, 1998, versión on-line.

DE VEGA, P., "Significado constitucional de la representación política”, Revista de Estudios Políticos (Nueva Época), n. 44/1985, pp. 25-45.

DEL CAMPO URBANO, S. / TEZANOS TORTAJADA, J.F. / SANTÍN, W., “La élite política española y la transición a la democracia”, Sistema: Revista de ciencias sociales, n. 48/1982, pp. 21-62.

DELGADO-IRIBARREN GARCÍA-CAMPERO, M., "El sistema electoral español: logros y deficiencias”, KÖLLING, M. (Coord.), Conferencia Los sistemas electorales español y alemán. Un debate de sus efectos, límites y propuestas de reforma, Fundación Manuel Giménez Abad de Estudios Parlamentarios y del Estado Autonómico, Zaragoza, 2012, pp. 13-49.

DYE, T.R., Who is running America, Prentice Hall, New Jersey, 1976.

FENICHEL PITKIN, H., El concepto de representación, Centro de Estudios Políticos y Constitucionales, Madrid, 2014.

FREIJEDO, F.J., "Derecho de participación a través de representantes y función constitucional de los partidos políticos”, Revista Española de Derecho Constitucional, n. 21/1987, pp. 199-228.

GARCÍA PELAYO, M., Las transformaciones del Estado contemporáneo, Alianza Editorial, Madrid, 1977.

GARCÍA ROCA, J., Cargos públicos representativos. Un estudio del artículo 23.2 de la Constitución, Aranzadi, Navarra, 1999.

GARRORENA MORALES, A., Escritos sobre la democracia. La democracia y la crisis de la democracia representativa, Centro de Estudios Políticos y Constitucionales, Madrid, 2015.

--, Representación política y Constitución democrática, Cuadernos Civitas, Madrid, 1991.

GIMÉNEZ MARTÍNEZ, M.A., "Renovación y continuidad de la élite política española durante la transición a la democracia: el caso de las cortes constituyentes (19771979)”, Historia constitucional: Revista Electrónica de Historia Constitucional, n. 15/2014, pp. 255-277.

GONZÁLEZ RODRÍGUEZ, J.J., "Escenarios de futuro para la democracia española. Democracia de partidos y democracia de audiencia”, NAVAJAS ZUBELDÍA, C. / ITURRIAGA BARCO, D. (Coords.), España en democracia: Actas del IV Congreso de Historia de Nuestro Tiempo, 2014, pp. 123-131.

GREPPI, A., Teatrocracia. Apología de la representación, Trotta, Madrid, 2016.

Revista de Estudios Jurídicos no 18/2018 (Segunda Época)

ISSN-e 2340-5066. Universidad de Jaén (España)

Versión electrónica: rej.ujaen.es 
GUTIÉRREZ GUTIÉRREZ, I., La democracia indignada. Tensiones entre voluntad popular y representación política, Comares, Granada, 2015.

HOBBES, T., Leviathan, Alianza Editorial, Madrid, 2004.

KOUNG, Y., Théorie constitutionnelle de Sieyès, París, 1934.

LAGO PEÑAS, S., "El sistema electoral español: una cuantificación de sus efectos "mecánico" y "psicológico"”, Revista de Estudios Políticos, n. 107/2000, pp. 225-250.

LAPORTA SAN MIGUEL, F.J., "El cansancio de la democracia”, Claves de la razón crítica, n.99/2000, pp. 20-25) o a Torres Moral como un mandato imperativo de partidos TORRES DEL MORAL, A., "Réquiem por el mandato representativo", Revista de Derecho Político, n. 81/ 2011, pp. 11-60).

LOEWENSTEIN, K., Teoría de la Constitución, Ariel, Barcelona, 1986.

LÓPEZ BASAGUREN, A., "Escocia: El referéndum sobre la independencia de Escocia y la propuesta de reforma de la devolution”, Revista Española de Derecho Constitucional, n. 104/2015, pp. 135-167.

MAÍZ SUÁREZ, R., "El Dios mortal ¿implica la globalización una progresiva desaparición del Estado?”, Araucaria: Revista Iberoamericana de filosofía, política y humanidades, vol. 19, núm. 37, 2017, pp. 21-43.

MANIN, B., Los Principios del Gobierno Representativo, Alianza Editorial, Madrid, 1997.

MANSBRIDGE, J., “Rethinking representation”, American Political Science Review, n. 4/2003, pp. 515-528.

MARTINES, T.: Diritto costituzionale, Giuffre, Milán, 2013.

MARTÍNEZ, A. / CRESPO MARTÍNEZ, I., "Receptividad y accountability en España”, MARTÍNEZ, A. (Coord.), Representación y calidad de la democracia en España, Tecnos, Madrid, 2006, pp. 101-116.

MICHELS, R., Los partidos políticos, Amorrortu Editores España, Buenos Aires, 1993.

MONTALVO JÄÄSKELÄINEN, F., "Multipartidismo territorial y forma de gobierno parlamentaria: la West Lothian Question como paradigma de los efectos del fenómeno”, Revista Española de Derecho Constitucional, n. 115/2015, pp. 81-142.

MONTESQUIEU, CH. L., El espíritu de las leyes, Alianza Editorial, Madrid, 2015.

PAJA FANO, M., “Un nuevo marco legal para la evaluación”, Gestión y análisis de políticas públicas, n. 17/2017, pp. 6-25.

PARETO, V., Forma y equilibrios sociales (extracto del Tratado de Sociología General), Alianza Editorial, Madrid, 1980.

PORTERO MOLINA, J.A., "Sobre la representación política”, Revista del Centro de Estudios Constitucionales, n. 10/1991, pp. 89-119.

PUTNAM, R.E., The comparative study of political elites, Prentice Hall, New Jersey ,1976.

RAMÍREZ NÁRDIZ, A., Democracia participativa. La experiencia española contemporánea, Universidad de Alicante, Alicante, 2009.

RIDAURA MARTÍNEZ, M.J., Representación política y parlamentarismo multinivel, Tirant lo Blanch, Valencia, 2014.

ROSANVALLON, P., La legitimidad democrática. Imparcialidad, reflexividad y proximidad, Paidós, Barcelona, 2008. 

Madrid, 2007.

ROUSSEAU, J.J., El contrato social o principios de derecho político, Tecnos, 1993.

SABINE G., Historia de la teoría política, Fondo de Cultura Económica, Madrid,

SARTORI, G., ¿Qué es la democracia?, Taurus, Madrid, 2007.

--, “En defensa de la representación política”, Claves de la Razón Práctica, n. 91/1999, pp. 2-6.

SCHMITT, C., Sobre el parlamentarismo, Madrid, Tecnos, 1990.

SEIJAS VILLADANGOS, $\mathrm{M}^{\mathrm{a}}$. E., "Los gobiernos de los Estados de la Unión Europea”, MATIA PORTILLA, F.J. (Coord.), Pluralidad territorial, nuevos derechos y garantías, Comares, Granada, 2012, pp. 117-145.

--, "Representación democrática, partidos políticos y tránsfugas”, Teoría y Realidad Constitucional, n.6/2000, pp. 163-188.

STUART MILL, J., Libertad. Gobierno representativo. Esclavitud femenina, Tecnos, Madrid, 1965.

TORRES DEL MORAL, A., "Democracia y representación en los orígenes del Estado constitucional, Revista de estudios políticos, n. 203/1975, pp. 145-212.

TOUCHARD, J., Historia de las ideas políticas, Tecnos, Madrid, 1990.

URIARTE BENGOETXEA, E., "El análisis de las élites políticas en las democracias”, Revista de Estudios Políticos, n. 97/1997, pp. 249-275.

VALENCIA ESCAMILLA, L., "Representatividad, legitimidad y credibilidad parlamentaria”, Revista Mexicana de Ciencias Políticas y Sociales, n. 162/1995, pp. 7378.

VÍRGALA FORURIA, E., "Representación, parlamentarismo y democracia participativa en España”, GARCÍA HERRERA, M.A. / ASENSI SABATER, J. / BALAGUER CALLEJÓN, F. (Coords.), Constitucionalismo crítico, Liber amicorum Carlos de Cabo Martín, Tomo II, Tirant lo Blanch, Valencia, 2016, pp. 1124-1134.

WEBER, M., Economía y sociedad, Fondo de cultura económica, México, 1992. 